\title{
Ouderenzorg verenigt zeven generaties
}

\author{
Vier generaties zorgwerkers leveren straks ouderenzorg aan drie \\ generaties zorgvragers. Het is hoog tijd voor generatiemanagement \\ voor een toekomstbestendige ouderenzorg.
}

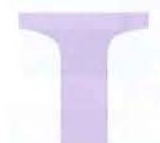

Het generatiedenken doet weer opgeld door de samenloop van vergrijzing, recessie en bezuinigingen op onderwijs, zorg en maatschappelijke dienstverlening. De nieuwe generatiedynamiek komt scherp aan het licht in de ouderenzorg, bij uitstek een werkveld met en tussen diverse generaties, in allerlei ruilrelaties van zorg geven en ontvangen.

De geïnstitutionaliseerde solidariteit op basis van een verplichting omdat we met z'n allen deel uitmaken van eenzelfde rechtsstaat, erodeert in onze huidige maatschappelijke context. Burgers worden steeds kritischer op autoritaire machtsstructuren, instituties, overheden en politiek. Impliciete generatie- en solidariteitscontracten komen onder druk te staan en vergen vernieuwing.

Het generatiecontract is een stilzwijgende afspraak in de samenleving dat jongeren voor ouderen zorgen, zodra de ouderen hulpbehoevend worden. Terugbetaling van de zorg geschiedt niet aan de generatie van de jongeren, maar later door een weer jongere generatie.

Op het niveau van de samenleving dwingt het generatiecontract tot het opbrengen van de vergrijzingskosten van pensioenen en ouderenzorg. Op het niveau van intermenselijke relaties gaat het bij het generatiecontract om hulp in geld en zorgverlening tussen leden van eenzelfde familie.

\section{Minder steun}

Het is minder vanzelfsprekend dat iedere generatie het beter heeft en doet dan de vorige, zo laat het Sociaal en Cultureel Planbureau (SCP) zien in Wisseling van de wacht. Het SCP signaleert daarin dat jongvolwassenen meer en langer ouderlijke financiële steun behoeven dan vroeger. Over hun hele levensloop geven kinderen duidelijk minder steun aan hun ouders dan zij andersom ontvangen, wellicht door de slechtere sociaaleconomische situatie. De relaties tussen nieuwe generaties van ouders, kinderen en kleinkinderen zijn gemiddeld wel veel hechter, warmer en persoonlijker geworden, meer op voet van gelijkheid dan gezag. Familierelaties die meerdere generaties omvatten, worden belangrijker door onder andere langere levensduur, uitstel van huwelijks- en gezinsvorming en toenemende instabiliteit van partnerrelaties.
Mantelzorg blijft stevig geworteld in de samenleving, maar heeft grenzen in duur en belasting van de persoon en het eigen gezin. Met een terugtredende overheid wordt dit een extra uitdaging. Het is noodzakelijk nieuwe vormen van organische en individuele solidariteit te ontwikkelen. Niet alleen tussen jong en oud, maar ouderen in de derde levensfase zullen meer solidariteit met ouderen in de vierde levensfase moeten opbrengen. Op het microniveau van de eigen familie is die solidariteit vanzelfsprekender dan op het macroniveau, dat blijkt wel uit de heftige debatten over AOW/pensioen en meer recent de mantelzorg.

\section{Spanningen}

Niet alleen binnen families, ook op de werkvloer in de (ouderen)zorg speelt het generatiedenken een belangrijke rol. Aart Bontekoning doet daar interessant onderzoek naar. Terwijl de zorginhoudelijke ontwikkelingen vragen om integrale zorgarrangementen vanuit wisselende multidisciplinaire teams, maken generatie-ontwikkelingen die juist steeds ingewikkelder. Verschillende werkgeneraties hebben kenmerken, gedragspatronen en 


\section{Robbert Huijsman}

Bijzonder hoogleraar Management \& Organisatie van de ouderenzorg en senior manager kwaliteit \& Innovatie bij Achmea divisie Zorg \& Gezondheid. Dit essay is gebaseerd op de oratie die hij op 20 juni uitspreekt aan de Erasmus Universiteit in Rotterdam.

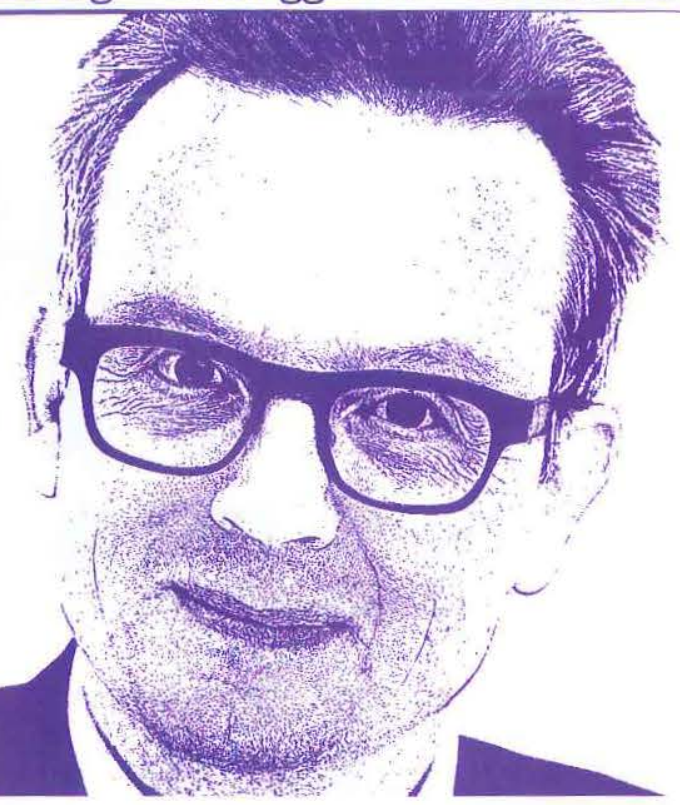

behoeften die sterk verschillen, van de oudste ervaren Babyboomers tot de jongste stagiaires uit de binnenkort instromende Digigeneratie (zie kader). Dat kan leiden tot spanningen met negatieve gevolgen op de samenwerking en productiviteit van teams.

Ook verschuiven de zorgrelaties met cliëntgroepen uit steeds meer generaties van steeds meer diverse ouderen. Gelijktijdig ontstaan ook nieuwe generaties mantelzorgers en vrijwilligers, met andere drijfveren en behoeften dan vorige generaties, maar ook grotere druk om actief te zijn in de civil society. Een boeiend en potentieel conflictrijke mengeling waarin nog weinig inzicht is.

Enkele observaties vanuit Bontekonings werk helpen. De Protestgeneratie heeft haar stempel gedrukt op onze (zorg)organisaties, maar door alles vast te willen leggen, laat ze structuren verstarren. Nu lijkt deze generatie weinig behoefte te hebben aan verandering en zo lang mogelijk vast te houden aan de macht. Het is een grote generatie waardoor haar invloed langer en groter zal zijn. Maar deze generatie stroomt nu massaal weg van de werkvloer. Generatie X neemt de leidinggevende

\section{'Deze leiders zijn inspirators in, plaats van overtuigers}

rol meer en meer over. Als nieuwe leiders zijn ze vooral gericht op het samen doen, het leveren van toegevoegde waarde, duurzame processen en het constructief benutten van de toenemende diversiteit. In tegenstelling tot de Babyboomers zoeken ze niet per se naar het allerbeste idee en breed draagvlak binnen de organisatie. Generatie X streeft meer naar optimale combinaties van verschillende ideeën. Deze leiders zijn inspirators in plaats van overtuigers: ze maken medewerkers bewust van wat er aan de hand is, sporen mensen aan om zelf initiatief en verantwoordelijkheid te nemen.

Dat is maar goed ook, want de waardeen gedragspatronen van de jongere generaties zullen zich niet meer automatisch aanpassen aan bestaande organisatieculturen, besluitvormingsprocedures en leiderschapsstijlen. De veranderingen die de Pragmatische en Grenzeloze generaties met zich meebrengen, zullen diep ingrijpen in organisaties en hun werkwijze. De voorgaande generaties waren vooral gedreven door maatschappelijke en sociale ontwikkelingen, veel meer gestuurd door hun opvattingen, normen en waarden.

De jongere generaties zijn vooral gevormd door de ontwikkelingen in de informatietechnologie. Deze generaties leren, werken en communiceren heel anders. In het harnas van grote organisaties en verouderde werkwijzen, verliezen zij werkenergie en werklust. Deze generaties hechten grote waarde aan authenticiteit en persoonlijke ontwikkeling en stappen bij teleurstelling makkelijk over naar andere werkgevers. Het succes van Buurtzorg is hiervan een voorbode.

\section{Nieuwe ruilrelaties}

Jonge en oudere generaties zorgprofessionals moeten samen de zorg 
leveren aan nieuwe generaties ouderen die zelfbewuster, koopkrachtiger en veeleisender worden. In het nieuwe gebiedsgerichte werken in vele gemeenten liggen kansen om generaties in straten en buurten bijeen te brengen.

\section{Met en tussen generaties}

Werken in de ouderenzorg is dus werken met en tussen generaties. Nieuwe leiders en managers van zorgorganisaties staan voor de uitdaging generatiemanagement te ontwikkelen dat leidt tot een vruchtbare dynamiek tussen vier generaties zorgprofessionals en dric gencraties zorgvragers.

Het gaat over de vraag hoe verschillende generaties in multidisciplinaire teams van en met elkaar kunnen leren,

\section{De generaties}

De Nederlandse socioloog Henk Becker nam trendbreuken als uitgangspunt om generaties te definiëren. De ouderen van nu komen uit de Vooroorlogse generatie en de Stille generatie met relatief veel vertrouwen in overheid en collectieve voorzieningen. De Protestgeneratie is goed opgeleid, sociaal vaardig en opgegroeid met ongekende welvaartsstijging. Generatie X kreeg veel opleiding, maar minder banen. De volgende generatie haalde hen in op de arbeidsmarkt. Dat heeft Generatie $X$ voorzichtig, nuchter en geduldig gemaakt. De Pragmatische Generatie $Y$ ontplooit zich zelf in (kennis)netwerken op meer informele basis. De Grenzeloze en de Digigeneratie zijn minder geneigd tot aanpassen. Ze worden opgevoed met de desastreuze gevolgen van niet duurzaam ondernemen. Ze netwerken (digitaal) met mensen van alle leeftijden en culturen. effectief samenwerkend en gebruik makend van elkaars aanvullende competenties en drijfveren. Hoe ga je bijvoorbeeld als manager uit Generatie $\mathrm{Y}$ of als directeur uit de Babyboomgeneratie om met nieuwe talenten uit de Grenzeloze en Digigeneratie? Die vragen tegelijkertijd verantwoordelijkheid én bescherming, willen in een hecht team werken, maar vragen flexibiliteit in werkplek en werktijd, maar ook directe feedback op prestaties. Jonge werknemers in de zorg zien zichzelf geconfronteerd met lastige sociaaleconomische ontwikkelingen, maar zijn vanuit hun overtuiging authentiek en gericht op duurzaamheid. Dat verbindt, zeker als zij veel meer gebruik maken van de kennis, ervaring en vaardighe- den van ouderen, maar ook vice versa. Samen leren met ouderen die voor en na de verschuivende pensioenleeftijd langer en actiever willen participeren; sociaal, economisch, politiek en cultureel. Binnen zorgorganisaties wordt het teamwerk van zelfsturende en continu in het werk lerende professionals zonder hiërarchie en bureaucratie de hoofdstroom. Managers worden informatiedelers die voortdurend bezig zijn in het veld teams te verbinden. Leiders stimuleren tot grensoverschrijdend werken tussen deelstelsels van zorg, welzijn en wonen.

Samen toegevoegde waarde leveren aan allerlei generaties ouderen, dat is de uitdaging waarvoor generatiemanagement in de ouderenzorg staat.

\begin{tabular}{|c|c|c|}
\hline Generatie & Geboortejaren & Kenmerken \\
\hline Vooroorlogse Generatie & $1910-1925$ & $\begin{array}{l}\text { Conventionele waarden, } \\
\text { kerkelijke verzuiling. }\end{array}$ \\
\hline Stille generatie & $1925-1940$ & $\begin{array}{l}\text { Gezagsgetrouwe burgerwaarden, } \\
\text { hard werken. }\end{array}$ \\
\hline $\begin{array}{l}\text { Protestgeneratie der } \\
\text { babyboomers }\end{array}$ & $1940-1955$ & $\begin{array}{l}\text { Idealistische en gedreven } \\
\text { democratiseerders emancipatie. }\end{array}$ \\
\hline $\begin{array}{l}\text { Verbindende of verloren } \\
\text { generatie }(X)\end{array}$ & $1955-1970$ & Nuchtere verbinders van diversiteit \\
\hline Pragmatische generatie $(\mathrm{Y})$ & $1970-1985$ & $\begin{array}{l}\text { Werk is belangrijk, levensgeluk } \\
\text { nog belangrijker. }\end{array}$ \\
\hline $\begin{array}{l}\text { Grenzeloze generatie } \\
\text { of generatie Einstein }\end{array}$ & $1985-2000$ & $\begin{array}{l}\text { Projectwerken, zonder hiërarchie } \\
\text { en bureaucratie. }\end{array}$ \\
\hline Digigeneratie (Z) & $2000-2015$ & $\begin{array}{l}\text { Authenticiteit, leren in het nieuwe } \\
\text { digitale werken, multitasking in the } \\
\text { cloud, duurzame footprint }\end{array}$ \\
\hline
\end{tabular}

